\title{
PENGARUH PENGGUNAAN YOUTUBE TERHADAP HASIL BELAJAR MAHASISWA
}

\author{
Denok Julianingsih ${ }^{1}$, Evi Widayanti ${ }^{2}$ \\ ${ }^{, 1,2}$ Program Studi Pendidikan Matematika, STKIP Bina Insan Mandiri \\ Email: denokjulianingsih@stkipbim.ac.id
}

\begin{abstract}
Abstrak:
Tujuan dari penelitian ini adalah untuk mengetahui pengaruh penggunaan media youtube terhadap hasil belajar mahasiswa pada perkuliahan Statistika semester genap 2020/2021 dan melihat respon mahasiswa selama menggunakan media youtube sebagai sumber informasi pembelajaran saat perkuliahan berlangsung. Penelitian ini merupakan penelitian eksperimen semu dengan subjek penelitian berjumlah 18 mahasiswa yang mengampu matakuliah statistika. Desain pada penelitian ini menggunakan one group pretest-posttest design. Instrumen yang digunakan pada penelitian ini adalah soal tes hasil belajar dan angket respon mahasiswa. Teknik analisis data yang digunakan menggunakan analisis statistik deskriptif dan analisis statistik inferensial. Data tersebut diolah menggunakan SPSS 22. Berdasarkan hasil analisis statistik inferensial menggunakan uji paired sample t-test didapatkan nilai alpha sebesar $0.000<0.05$ artinya ada pengaruh penggunaan media youtube terhadap hasil belajar mahasiswa. Hal ini dapat dilihat ada perbedaan rata-rata hasil belajar sebelum dan sesudah penggunaan youtube yaitu sebesar 54.44. Selain itu berdasarkan hasil angket respon mahasiswa menunjukkan bahwa semua aspek yang terkandung dalam angket respon mahasiswa rata-rata menunjukkan hasil yang baik yaitu sebesar 67.36.
\end{abstract}

Kata Kunci: youtube, hasil belajar, media pembelajaran, respon mahasiswa

\begin{abstract}
:
The purpose of this study was to determine the effect of using youtube media on student learning outcomes in the even semester 2020/2021 Statistics lectures and to see student responses while using youtube media as a source of learning information during lectures. This research is a quasi-experimental research with 18 students taking the subject of statistics. The design in this study used a one group pretest-posttest design. The instruments used in this study were a matter of learning outcomes tests and student response questionnaires. The data analysis technique used was descriptive statistical analysis and inferential statistical analysis. The data was processed using SPSS 22. Based on the results of inferential statistical analysis using the paired sample t-test, an alpha value of $0.000<0.05$ means that there is an effect of using YouTube media on student learning outcomes. It can be seen that there is a difference in the average learning outcomes before and after using YouTube, which is 54.44. In addition, based on the results of the student response questionnaire, it showed that all aspects contained in the student response questionnaire showed an average of 67.36 good results.
\end{abstract}

Keywords: youtube, learning outcomes, learning media, student responses

\section{Pendahuluan}

Pandemi Covid-19 yang melanda Indonesia semenjak 2 Maret 2020 menyebabkan sistem pembelajaran berlangsung secara daring. Pembelajaran secara daring dalam upaya untuk memutus penyebaran rantai Covid-19 yang disebabkan oleh virus SARS-CoV-2 atau Severe Acute Respirotory Syndrome Coronavirus-2 (Ilimu et al., 2020).
Pembelajaran yang diberlakukan secara online ini menuntut dosen untuk lebih kreatif dalam mengembangkan metode pembelajaran atau menggunakan media pembelajaran yang tepat agar pembelajaran tetap berlangsung secara maksimal. Pembelajaran daring adalah pembelajaran yang dilaksanakan secara online dengan memanfaatkan internet selama pembelajaran berlangsung. Pembelajaran daring dapat dilaksanakan 
secara fleksibel kapanpun dan dimanapun (Purniawan \& Sumarni, 2020).

Pembelajaran daring ini dapat memanfaatkan beberapa media aplikasi seperti Whatsapp, Zoom, Google Classroom, Google Meet, Youtube, Edmodo, e-Campus, Google Chat, Line, Moodle, Quipper, Schology (Ningsih \& Rahadi, 2020). Berdasarkan beberapa media aplikasi tersebut, tentunya perlu memperhatikan pemilihan media pembelajaran yang tepat selama pelaksanaan perkuliahan daring. Hal ini dikarenakan ada kemungkinan rendahnya kemampuan belajar mahasiswa . Tentu saja permasalahan ini tidak terlepas dari media pembelajaran yang digunakan oleh dosen selama perkuliahan daring (Pambudi et al., 2018).

Media pembelajaran sebagai salah satu sumber belajar yang dapat digunakan untuk membantu proses pembelajaran berlangsung. Sumber belajar yang tepat yang bisa digunakan selama perkuliahan daring yaitu berupa sumber belajar digital. Sumber belajar digital adalah kombinasi dari teks elektronik, grafik, gambar, video dan suara ke dalam lingkup lingkungan digital yang terstruktur yang dapat membuat orang berinteraksi (Arindiono dalam Julianiningsih, 2021).

Media pembelajaran yang dapat dimanfaatkan oleh dosen selama perkuliahan daring adalah dengan membuat video pembelajaran. Video pembelajaran yang telah dibuat oleh Dosen dapat diunggah melalui platform berbagi video terbesar di dunia yaitu Youtube. Youtube merupakan situs berbagi video yang sangat populer saat ini. Dimana mulai dari anakanak, remaja, sampai dewasa seringkali melihat video yang dibagikan lewat situs berbagi terbesar ini.

Youtube merupakan situs web video sharing yang didirikan pada Februari 2015 oleh tiga orang bekas karyawan PayPal yaitu Chad Hurley, Steve Chen dan Jawed Karim (Pambudi et al., 2018). Selain sebagai layanan video sharing, youtube juga dapat digunakan sebagai media publikasi dari para penyaji video yang dapat dimanfaatkan oleh pendidik maupun peserta didik sebagai media pembelajaran.
Lestari (2013) menambahkan bahwa youtube dapat dijadikan sebagai sumber belajar dan media pembelajaran yang dapat memenuhi tuntutan kebutuhan generasi digital. Pengguna dengan bebas dapat memilih konten video apa saja, yang sesuai dengan tema yang mereka butuhkan dari ratusan ribu video yang terdapat pada youtube.

Berdasarkan hasil riset yang dilakukan oleh Google bersama dengan PT. Kantar TNS Indonesia, rata-rata penonton Indonesia menghabiskan waktu selama 59 menit setiap harinya untuk menonton video di youtube. Sebanyak $92 \%$ pengguna internet Indonesia menyatakan bahwa youtube adalah tujuan utama mereka ketika mencari video. Sedangkan dari segi kuantitas penonton, youtube sudah menyaingi televisi sebagai sarana media yang diakses orang Indonesia (Setiadi et al., 2019).

Menurut (Tohari et al., 2019) Pembelajaran dengan video memiliki keuntungan yaitu dapat menghadirkan representasi gambar dan suara dari sebuah gagasan atau peristiwa kepada pembelajar di kelas. Dengan menggunakan video pembelajaran yang diunggah melalui youtube diharapkan hasil belajar mahasiswa cukup baik meskipun perkuliahan tidak dapat berlangsung secara tatap muka. Hasil belajar mahasiswa dipengaruhi oleh penggunaan bahan ajar yang digunakan (Angko dalam Tohari et al., 2019).

Keterbatasan ruang selama perkuliahan daring menjadi salah satu hambatan bagi dosen dalam menjelaskan materi perkuliahan maupun tutorial-tutorial yang seharusnya dapat ditunjukkan secara langsung. Dengan youtube ini, Dosen tetap dapat menyampaikan materinya maupun memberikan tutorial-tutorial melalui video yang sudah dibuat. Dengan begitu, diharapkan hasil belajar mahasiswa dapat meningkat meskipun perkuliahan hanya dilaksanakan secara daring.

Disisi lain, penelitian Wardani dkk dalam (Muntazhimah et al., 2020) mengungkapkan bahwa terdapat kelemahan pembelajaran dengan menggunakan youtube sebagai sumber belajar. Kelemahan tersebut seperti sulitnya melakukan 
sosialisasi antar siswa dan intensitas bertemu sangat minim sehingga siswa menjadi lebih sulit dalam memahami materi pembelajaran.

Hal ini mengindikasikan bahwa sangatlah penting untuk melihat respon atau persepsi mahasiswa terhadap perkuliahan daring menggunakan media youtube sebagai sumber belajar. Pentingnya persepsi yang baik dari mahasiswa terhadap perkuliahan daring menjadi salah satu syarat agar proses pembelajaran dapat berjalan dengan baik pula dan persepsi yang positif akan mempermudah pencapaian tujuan yang maksimal dalam pembelajaran (Muntazhimah et al., 2020).

Melihat hal tersebut, penelitian ini bertujuan untuk melihat ada atau tidaknya pengaruh penggunaan youtube sebagai sumber belajar terhadap hasil belajar mahasiswa. Selain itu, peneliti akan melihat respon mahasiswa selama penggunaan youtube sebagai sumber belajar saat perkuliahan daring.

\section{Metode Penelitian}

Penelitian ini merupakan eksperimen semu. Penelitian dilaksanakan selama masa pandemi pada mahasiswa keguruan pendidikan guru sekolah dasar semester genap 2020/2021 STKIP Bina Insan Mandiri yang mengampu mata kuliah Statistika Pendidikan. Subjek pada penelitian ini berjumlah 18 mahasiswa. Penelitian dilakukan secara daring pada rentang waktu 06 Maret 2021 sampai dengan 24 Juli 2021.

Desain pada penelitian ini menggunakan one group pretest-posttest design. Dimana pada tahap awal sebelum perkuliahan dimulai, mahasiswa diberikan soal pretest untuk mengukur kemampuan awal mahasiswa terhadap pemahaman materi statistika. Soal pretest diberikan diberikan secara daring. Soal yang diberika terdiri dari 5 soal uraian. Selanjutnya, mahasiswa diberikan perlakuan selama perkuliahan berlangsung menggunakan media youtube sebagai sarana mentransfer informasi dari dosen ke mahasiswa. Tahapan terakhir setelah adanya perlakuan adalah pemberian soal posttest untuk mengukur kemampuan akhir mahasiswa terhadap pemahaman materi yang sudah disampaikan melalui media youtube. Soal posttest diberikan secara daring yang terdiri dari 5 butir soal uraian.

Teknik pengumpulan data yang digunakan pada penelitian ini berupa tes hasil belajar dan respon mahasiswa selama penggunaan media youtube pada perkuliahan. Tes hasil belajar digunakan untuk melihat pengaruh penggunaan youtube terhadap hasil belajar mahasiswa. Sedangkan angket respon mahasiswa digunakan untuk melihat respon atau tanggapan mahasiswa selama menggunakan media youtube saat perkuliahan berlangsung. Angket respon mahasiswa diberikan di akhir perkuliahan, yang dibagikan melalui link google form. Instrumen yang digunakan adalah soal tes hasil belajar mahasiswa dan angket respon mahasiswa.

Data hasil penelitian ini dianalisis menggunakan statistik inferensial yaitu uji perbedaan rata-rata. Sebelum melakukan uji perbedaan rata-rata, terlebih dahulu dilakukan uji normalitas. Uji normalitas merupakan uji asumsi klasik yang digunakan sebagai prasyarat awal untuk melihat apakah data tersebut berdistribusi normal atau tidak. Jika data yang dianalisis berdistribusi normal maka statistik inferensial yang digunakan adalah statistic parametrik yaitu Uji Paired Sample t-Test. Sedangkan, jika data hasil analisis tidak berdistribusi normal maka statistik inferensial yang digunakan adalah statistic non parametrik yaitu Uji Wilcoxon Signed Rank Test. Penggunaan Uji Wilcoxon Signed Rank Test dikarenakan peneliti melakukan uji perbedaan rata-rata di satu kelas.

\section{Hasil dan Pembahasan Hasil}

Deskripsi data pada penelitian ini dianalisis menggunakan statistik deskriptif berupa hasil pretest dan posttest dapat dilihat pada tabel berikut ini.

Tabel 1. Analisis Statistik Deskriptif

\begin{tabular}{lccccc}
\hline & $\mathrm{N}$ & Min & Max & Mean & SD \\
\hline Pretest & 18 & 20.0 & 45 & 30.27 & 8.12 \\
Posttest & 18 & 68.5 & 99.4 & 84.71 & 10.10 \\
\hline
\end{tabular}


Berdasarkan hasil analisis deskriptif pada Tabel 1 terlihat bahwa dari 18 mahasiswa yang telah mengikuti perkuliahan statistik dengan menggunakan media youtube didapatkan rata-rata hasil belajar siswa sebesar 84.71 dengan perolehan nilai maksimal di kelas sebesar 99.4 dengan standar deviasi sebesar 10.10. Hasil ini cukup baik dibandingkan pada saat tes awal, rata-rata hasil belajar mahasiswa hanya sebesar 30.27 dengan perolehan nilai maksimal di kelas sebesar 45 dengan standar deviasi sebesar 8.12. Jika dilihat ada perbedaan rata-rata sebelum dan sesudah penggunaan youtube yaitu sebesar 54.44 dimana hasil belajar mahasiswa lebih baik setelah penggunaan media youtube. Tentu saja hasil ini perlu diuji secara statistik inferensial untuk melihat apakah ada perbedaan rata-rata secara signifikan. Untuk itu perlu dilakukan uji beda yang mana sebelumnya dilakukan Uji Normalitas terlebih dahulu.

Berikut ini adalah hasil dari Uji Normalitas pada data hasil belajar mahasiswa sebelum dan sesudah menggunakan media youtube saat perkuliahan.

Tabel 2. Hasil Uji Normalitas

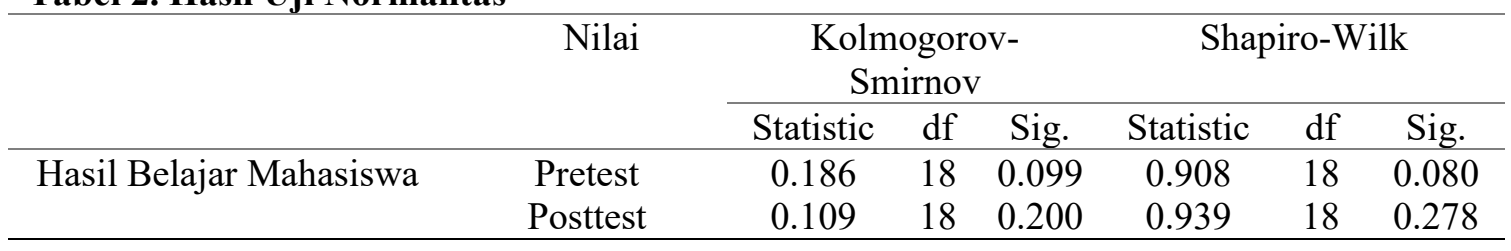

Tabel di atas merupakan hasil dari uji normalitas pada data hasil belajar mahasiswa. Berikut ini adalah dasar pengambilan keputusan pada Uji Normalitas (Santoso, 2020):

1. Jika nilai signifikansi $<0.05$ maka data tidak berdistribusi normal.

2. Jika nilai signifikansi $>0.05$ maka data berdistribusi normal.

Berdasarkan hasil Uji Normalitas pada Tabel 2. Terlihat nilai signifikansi pretest pada bagian Kolmogorov-Smirnov maupun Shapiro-Wilk $>0.05$ yaitu $0.099>$ 0.05 dan $0.200>0.05$. Sedangkan nilai signifikansi posttest pada bagian Kolmogorov-Smirnov maupun ShapiroWilk $>0.05$ yaitu $0.080>0.05$ dan $0.278>$ 0.05. Dari hasil tersebut diperoleh kesimpulan bahwa data hasil belajar mahasiswa baik pretest dan posttest berdistribusi normal. Sehingga, analisis statistic inferensial yang digunakan menggunakan statistik parametrik yaitu $U j i$ Paired Sample t-Test.

Berikut ini adalah hasil dari $U j i$ Paired Sample t-Test yang disajikan pada Tabel. 3
Tabel 3. Hasil Uji Paired Sample t-Test.

\begin{tabular}{lc}
\hline & Pretest-Posttest \\
\hline Mean & -54.43333 \\
Standar Deviasi & 7.73518 \\
$\mathrm{t}$ & -29.856 \\
$\mathrm{df}$ & 17 \\
Sig. (2 tailed) & 0.000 \\
\hline
\end{tabular}

Dasar pengambilan keputusan pada Uji Paired Sample t-Test adalah sebagai berikut (Santoso, 2020):

1. Jika probabilitas atau nilai siginifikansi (2 tailed $)>0.025$ maka Ho diterima dan Ha ditolak.

2. Jika probabilitas atau nilai signifikansi $(2$ tailed $)<0.025$ maka Ho ditolak dan Ha diterima. ini adalah:

Sedangkan hipotesis pada penilitian

1. tidak ada perbedaan rata-rata secara nyata antara hasil belajar mahasiswa sebelum menggunakan media youtube dan sesudah menggunakan media youtube. Artinya tidak ada pengaruh penggunaan youtube terhadap hasil belajar mahasiswa.

2. ada perbedaan rata-rata secara nyata antara hasil belajar sebelum menggunakan media youtube dan sesudah menggunakan media youtube. 
Artinya ada pengaruh penggunaan youtube terhadap hasil belajar mahasiswa.

Berdasarkan hasil Uji Paired Sample t-Test pada Tabel 3 terlihat nilai siginifikansi (2 tailed) sebesar 0.000 yang mana nilai tersebut kurang dari 0.05 maka Ho ditolak dan Ha diterima. Sehingga, ada perbedaan rata-rata hasil belajar sebelum menggunakan media youtube dan sesudah menggunakan media youtube. Artinya ada pengaruh penggunaan youtube terhadap hasil belajar mahasiswa. Dengan kata lain, penggunaan youtube pada perkuliahan statistika selama masa pandemi adalah efektif untuk meningkatkan hasil belajar mahasiswa.

Setelah mengetahui bahwa penggunaan youtube efektif untuk meningkatkan hasil belajar mahasiswa, selanjutnya di akhir perkuliahan Dosen membagikan angket respon mahasiswa yang berisi tanggapan mahasiswa selama perkuliahan berlangsung menggunakan youtube sebagai sumber belajar.

Berikut ini adalah grafik respon mahasiswa terhadap penggunaan youtube sebagai media pembelajaran.

\section{Respon Mahastose}

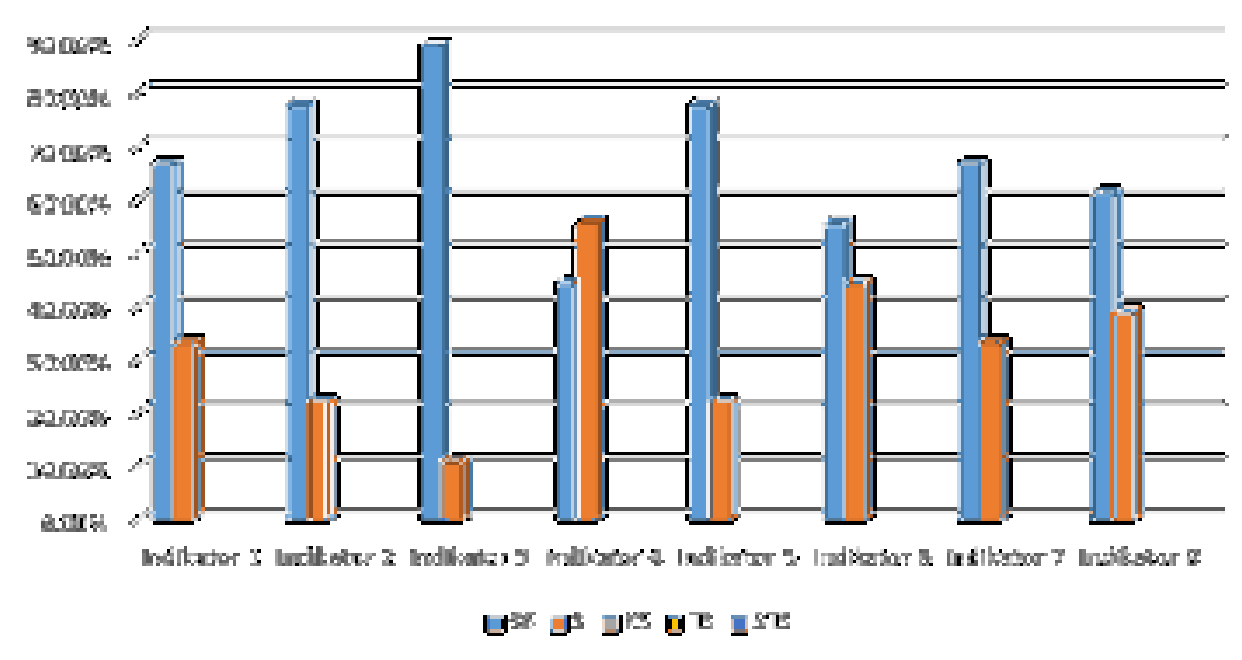

\section{Gambar 1. Hasil Analisis Angket Respon Mahasiswa pada Penggunaan Youtube sebagai Media Pembelajaran.}

Pada grafik di atas terlihat mahasiswa rata-rata memberikan responnya pada pilihan sangat setuju dan setuju. Dimana masing-masing indikator pada angket respon mahasiswa tersebut menyatakan senang saat pembelajaran daring menggunakan media youtube. Indikator angket respon yang kedua menyatakan dapat memahami materi perkuliahan dengan baik dan lebih mudah melalui media youtube. Indikator ketiga menyatakan mudah mempraktekkan olah data SPSS melalui tutorial dari youtube. Indikator keempat adalah dapat termotivasi belajar selama dengan menggunakan youtube sebagai platform belajar daring.
Indikator kelima menyatakan bahwa penyampaian materi dan tutorial SPSS yang disajikan pada youtube sangat jelas dan mudah dipahami. Indikator keenam menyatakan bahwa pembelajaran dengan menggunakan media youtube lebih baik dibandingkan hanya metode ceramah via video conference. Pada indikator ketujuh menyatakan bahwa pembelajaran statistika menggunakan media youtube dapat mendorong untuk mendapatkan hasil belajar maksimal. Sedangkan indikator terakhir adalah mendorong rasa semangat untuk menyelesaikan tugas yang diberikan Dosen selama pembelajaran statistika menggunakan media youtube. 


\section{Pembahasan}

Berdasarkan hasil analisis statistik deskriptif yang disajikan pada Tabel 1, terlihat bahwa hasil belajar mahasiswa mengalami kenaikan dari yang sebelum mendapatkan perlakuan berupa penggunaan media youtube dan setelah penggunaan media youtube. Rata-rata peningkatan hasil belajar mahasiswa sebesar 54.44. Hasil ini didapatkan dari selisih perbedaan rata-rata hasil belajar sebelum dan sesudah penggunaan media youtube. Dimana nilai pretest sebesar 30.27 dan posttest sebesar 84.71. Temuan ini sesuai dengan penelitian Bina yang mana ada peningkatan hasil kemampuan matematis mahasiswa sebelum menggunakan youtube dan sesudah menggunakan youtube yaitu sebesar 61.82 (Bina, 2021).

Berdasarkan penelitian Iwantara tahun 2014 menyatakan bahwa hasil belajar siswa yang menggunakan youtube lebih baik dibandingkan yang tidak menggunakan youtube. Perbedaan rata-rata sebesar 24.21 dengan nilai pretest sebesar 19.91 dan posttest sebesar 44.12 (Iwantara et al., 2014).

Respon mahasiswa di akhir perkuliahan rata-rata juga sangat bagus. Berdasarkan hasil analisis angket respon mahasiswa yang disajikan pada Gambar 1 terlihat pada indikator pertama sebanyak 12 mahasiswa atau sekitar $66.7 \%$ menyatakan sangat setuju pada pembelajaran daring menggunakan media youtube. Hanya 6 mahasiswa atau sekita $33.3 \%$ yang menyatakan setuju. Sedangkan pada indikator kedua sebesar $77.8 \%$ atau 14 mahasiswa menyatakan sangat setuju bahwa mereka dapat memahami materi perkuliahan dengan baik dan lebih mudah karena bantuan media youtube. Pada indikator ketiga sebanyak 16 mahasiswa atau sekitar $88.9 \%$ sangat setuju bahwa mereka dengan mudah dapat mempraktekkan olah data dengan SPSS melalui tutorial dari youtube.

Indikator keempat pada angket respon mahasiswa menyatakan bahwa penggunaan media youtube sebagai platform belajar daring, membuat belajar lebih termotivasi dijawab sangat setuju oleh 8 mahasiswa atau sekitar $44.4 \%$ sedangkan
10 mahasiswa lainnya menyatakan setuju. Pada indikator kelima sebanyak 14 mahasiswa menyatakan sangat setuju bahwa penyampaian materi dan tutorial SPSS yang disajikan pada channel youtube sangat jelas dan mudah dipahami. Indikator keenam sebesar $55.6 \%$ berpendapat sangat setuju bahwa pembelajaran daring menggunakan media youtube lebih baik dibandingkan hanya menggunakan metode ceramah via video conference. Dua indikator terakhir menyatakan sangat setuju pada pembelajaran statistika yang menggunakan media youtube karena dapat mendorong untuk mendapatkan hasil belajar maksimal yaitu sebesar $66.7 \%$ dan $61.1 \%$ sangat setuju bahwa pembelajaran statistika dengan media youtube dapat mendorong untuk semangat menyelesaikan tugas dari Dosen. Dari keseluruhan aspek di dalam angket respon mahasiswa tersebut didapatkan respon yang baik sebesar 67.36 menyatakan sangat setuju pada masingmasing indikator respon mahasiswa.

Penggunaan media youtube sebagai alternatif sumber belajar selama perkuliahan daring pada masa pandemi cukup efektif. Hal ini dikarenakan Dosen dapat membagikan informasi ataupun materi yang sulit dan juga materi perkuliahan yang mengedepankan pada tutorial olah data menggunakan SPSS yang dikemas dalam bentuk video pembelajaran. Hal ini sejalan dengan yang dikatakan oleh Busyaeri et al. (2016) yang menyatakan bahwa peserta didik akan lebih mudah memahami materi pembelajaran yang sulit ataupun materi yang membutuhkan praktikum melalui media video pembelajaran.

Dosen juga akan lebih leluasa membagikan materi melalui video dimana video tersebut tidak hanya disajikan berupa gambar, tulisan ataupun animasi lainnya tetapi juga didukung dengan adanya audio. Sehingga hal ini cukup menarik bagi mahasiswa dimana mahasiswa seakan-akan seperti mendengar penjelasan langsung dari Dosennya meskipun tidak berhadapan muka secara langsung. Selain itu intrepretasi mahasiswa terhadap pemahaman materi menjadikan lebih baik dikarenakan hal ini dapat membantu 
pemahaman konsep mahasiswa. Hal ini sejalan dengan yang diungkapkan oleh Iwantara et al., (2014) yang menyatakan bahwa youtube sebagai media pembelajaran lebih baik dibandingkan dengan media riil dalam hal indikator intrepretasi dikarenakan adanya animasi pada media video sehingga dalam memvisualisasikan konsep abstrak menjadi lebih nyata. Begitu pula pendapat yang diutarakan oleh Tutiasri et al., (2020) yang menyatakan bahwa media yang berbasis audio visual, selain lebih menarik dan dapat menimbulkan motivasi belajar, media audio visual juga dapat membuat hal abstrak menjadi lebih jelas.

Meskipun begitu pembelajaran daring menggunakan media youtube juga memiliki kelebihan dan kelemahan. Pada penelitian ini banyak sekali respon mahasiswa yang menyatakan bahwa penjelasan materi yang disampaikan pada video sangat jelas, detail, mudah dipahami, materi yang disampaikan lengkap dan menarik. Selain itu saat mereka lupa pada materi yang sudah ditonton, mereka dapat memutar videonya kembali atau sebelumnya sudah mereka download sehingga dapat ditonton ulang secara offline. Sedangkan kekurangan menggunakan media youtube sebagai alternatif media pembelajaran adalah terkendalanya masalah jaringan, sehingga seringkali loading, pengambilan suara yang kurang keras mengakibatkan audio yang terdengar di beberapa video cukup pelan, dan masalah kuota internet.

Permasalahan jaringan atau sinyal selular memang seringkali muncul selama pembelajaran daring. Hal ini dialami baik oleh pendidik maupun peserta didik. Begitu pula masalah kuota habis, atau belum membeli kuota internet juga menjadi kendala utama selama pembelajaran daring di masa pandemi COVID-19 (Ridha et al., 2021). Sebagai seorang Dosen yang menginginkan proses pembelajaran dengan lancar, terkadang saat perkuliahan online berlangsung tetap berada di lingkungan kampus agar bisa mendapatkan sinyal wifi yang lebih stabil dibandingkan jika berada di rumah. Sedangkan demi membantu kelancaran belajar mahasiswa, institusi memberikan potongan biaya SPP, yang harapannya mahasiswa dapat menggunakan biaya potongan tersebut untuk membeli pulsa selain mendapatkan kuota belajar dari Pemerintah yang memang pemerolehannya belum secara menyeluruh diterima oleh seluruh mahasiswa.

\section{Simpulan dan Saran Simpulan}

Penggunaan youtube sebagai media pembelajaran untuk melihat ada tidaknya pengaruh hasil belajar mahasiswa di saat perkuliahan daring di masa pandemi COVID-19 ini terbukti efektif terlihat dari adanya perbedaan rata-rata hasil belajar sebelum dan sesudah penggunaan media youtube yang artinya ada pengaruh penggunaan media youtube terhadap hasil belajar mahasiswa.

Respon mahasiswa selama menggunakan media youtube, juga sangat baik. Terlihat dari angket repon yang ratarata berpendapat sangat setuju pada masingmasing indikator penilaian.

\section{Saran}

Sebelum penggunaan media youtube sebagai alternatif sumber belajar mahasiswa, alangkah baiknya siapkan terlebih dahulu draft materi ataupun peralatan yang dibutuhkan selama pembuatan video seperti kamera, aplikasi perekam layar, handsfree, maupun pen tablet.

\section{Daftar Pustaka}

Bina, N. S. (2021). Pengaruh Platform Pembelajaran Daring Youtube Terhadap Kemampuan Matematis di Masa Pandemik Covid-19. Laplace: Jurnal Pendidikan Matematika, 4(1), 32-39.

https://doi.org/10.31537/laplace.v4il. 461

Busyaeri, A., Udin, T., \& Zaenudin, A. (2016). Pengaruh Penggunaan Video Pembelajaran terhadap Peningkatan Hasil Belajar Mapel IPA di Min Kroya Cirebon. Al Ibtida: Jurnal Pendidikan Guru MI, 3(1), 116-137. https://doi.org/10.24235/al.ibtida.snj. v3i1.584 
Ilimu, E., Kaliu, S., Tendrita, M., \& Suwo, R. (2020). MATAPPA: Jurnal Pengabdian Kepada Masyarakat Pembuatan Hand Sanitizer dari Bahan Alami sebagai Langkah Pencegahan Corona Virus Disease 2019 ( COVID-19). 3, 137-143.

Iwantara, I. ., Sadia, I. ., \& Suma, I. . (2014). Pengaruh Penggunaan Media Video Youtube dalam Pembelajaran IPA Terhadap Motivasi Belajar dan Pemahaman Konsep Siswa. EJournal Program Pascasarjana Universitas Pendidikan Ganesha, 4.

Julianiningsih, D. (2021). MATAPPA: Jurnal Pengabdian Kepada Masyarakat Bimbingan Teknis Pembuatan Media Pembelajaran Interaktif Berbasis Microsoft office Powerpoint dan Papan Tulis Digital . 4, 232-238.

Lestari, R. (2013). Penggunaan Youtube sebagai Media Pembelajaran Bahasa Inggris. Seminar Nasional Kedua Pendidikan Berkemajuan Dan Menggembirakan (The Second Progressive and Fun Education Seminar), 607-612. https://publikasiilmiah.ums.ac.id/bitst ream/handle/11617/9566/68.pdf?seq uence $=1 \&$ is Allowed $=\mathrm{y}$

Muntazhimah, M., Nasution, E. Y. P., \& Ningsih, S. Y. (2020). Respon Siswa Sekolah Menengah Terhadap Pembelajaran Matematika di Era COVID-19. Jurnal Pendidikan Matematika Universitas Lampung, $8(3)$, 193-206. https://doi.org/10.23960/mtk/v8i2.pp 193-206

Ningsih, I. P., \& Rahadi, D. R. (2020). Perilaku Mahasiswa Terhadap Pembelajaran Daring di Masa Pandemi Covid-19. Jurnal
Manajemen Bisnis (JMB), 33(2), 102-108.

Pambudi, R., Afghohani, A., \& Farahsanti, I. (2018). Pengaruh Media Video Youtube Terhadap Prestasi Belajar Matematika pada Siswa Kelas X SMK Negeri 2 Sukoharjo Tahun Ajaran 2017 / 2018. Jurnal Pendidikan, 28(2), 175-182.

Purniawan, \& Sumarni, W. (2020). Analisis Respon Siswa Pada Pembelajaran Daring di Masa Pandemi Covid 19. Seminar Nasional Pascasarjana UNNES, 784-789.

Ridha, M., Firman, \& Desyandri. (2021). Efektifitas Penggunaan Media Video pada Pembelajaran Tematik Terpadu di Sekolah Dasar Saat Pandemi Covid-19. Jurnal Pendidikan Tambusai, 5(1), 154-162. https://jptam.org/index.php/jptam/arti cle/view/925

Santoso, S. (2020). Panduan Lengkap SPSS 26. PT. Elex Media Komputindo.

Setiadi, E. F., Azmi, A., \& Indrawadi, J. (2019). Youtube Sebagai Sumber Belajar Generasi Milenial. Journal of Civic Education, 2(4), 313-323. https://doi.org/10.24036/jce.v2i4.135

Tohari, H., Mustaji, \& Bachri, B. S. (2019). Pengaruh Penggunaan YouTube Terhadap Motivasi Belajar dan Hasil Belajar Mahasiswa. Jurnal Teknologi Pendidikan, 07(01), 1-13.

Tutiasri, R. P., Laminto, N. K., \& Nazri, K. (2020). Pemanfaatan Youtube Sebagai Media Pembelajaran Bagi Mahasiswa di Tengah Pandemi Covid-19. Juurnal Komunikasi Masyarakat dan Keamanan (KOMASKAM), 2(2), 1-15. 